\title{
POSEBNA NAKNADA ZA TROŠKOVE PROUZROČENE VJEROVNIKU DUŽNIKOVIM ZAKAŠNJENJEM S ISPUNJENJEM NOVČANE OBVEZE U POSLOVNIM TRANSAKCIJAMA (PAUŠALNA NAKNADA TROŠKOVA NAPLATE)
}

\author{
Doc. dr. sc. Ivan Tot*
}

\author{
UDK.: 347.426 .6 \\ https://doi.org/10.30925/zpfsr.41.1.7 \\ Ur.: 13. siječnja 2020. \\ Pr.: 20. veljače 2020 . \\ Izvorni znanstveni rad
}

\begin{abstract}
Sažetak
Jedna od novina koju je u hrvatsko pravo unio Zakon o financijskom poslovanju i predstečajnoj nagodbi iz 2012. godine (ZFPPN) jest i uvođenje nove pravne posljedice dužničkoga zakašnjenja s plaćanjem $u$, tzv. poslovnim transakcijama. Odredbom čl. 13. st. 1. ZFPPN-a, vjerovnik novčane obveze ovlašten je ex lege zahtijevati od dužnika paušalnu naknadu u iznosu koji odgovara kunskoj protuvrijednosti iznosa od četrdeset eura. Ta paušalna naknada koju ZFPPN naziva „,posebnom naknadom za troškove prouzročene vjerovniku dužnikovim zakašnjenjem $s$ ispunjenjem novčane obveze u poslovnim transakcijama“ uvedena je u hrvatsko pravo radi usklađivanja s odredbama čl. 6. Direktive 2011/7/EU. U radu se raspravlja o njezinoj pravnoj prirodi i funkcijama te se analiziraju pretpostavke za nastanak vjerovnikova prava na paušalnu naknadu te dospjelost $i$ zastara zahtjeva za isplatom te naknade. U radu iznesena tumačenja odredaba ZFPPN-a temelje se na poredbenopravnoj analizi $i$ usklađenoj interpretaciji ZFPPN-a s Direktivom 2011/7/EU. U primjeni poredbenopravne metode razmatrana su stajališta austrijskog i njemačkog prava, a istraživanjem su obuhvaćeni i propisi svih država članica Europske unije kojima su one u nacionalnom pravu transponirale odredbe čl. 6. Direktive 2011/7/EU.
\end{abstract}

Ključne riječi: zakašnjenje s plaćanjem; poslovne transakcije; paušalna naknada troškova naplate; Direktiva 2011/7/EU.

\section{UVOD}

Odredbama Zakona o financijskom poslovanju i predstečajnoj nagodbi, ${ }^{1} \mathrm{u}$ hrvatsko pravo uvedeno je, među ostalim, posebno pravno uređenje rokova ispunjenja

* Dr. sc. Ivan Tot, docent, Ekonomski fakultet Sveučilišta u Zagrebu; itot@net.efzg.hr.

1 Zakon o financijskom poslovanju i predstečajnoj nagodbi, Narodne novine, br. 108/12., 144/12., 81/13., 112/13., 71/15., 78/15. (dalje u tekstu: ZFPPN). 
novčanih obveza te zateznih kamata i drugih pravnih posljedica dužnikova zakašnjenja s plaćanjem u, tzv. poslovnim transakcijama. ${ }^{2}$ Jedna je od novina i uvođenje dodatne pravne posljedice dužničkoga zakašnjenja s plaćanjem. Zakasni li dužnik s plaćanjem, on na temelju odredbe čl. 13. st. 1. ZFPPN-a ex lege vjerovniku novčane obveze duguje i posebnu, paušalnu naknadu troškova prouzročenih zakašnjenjem u kunskoj protuvrijednosti iznosa od četrdeset eura. ${ }^{3}$ Razlog za ovu novinu bilo je usklađivanje s odredbama Direktive 2011/7/EU. ${ }^{4}$ Njome su države članice Europske unije obvezane, među ostalim, u nacionalnom pravu predvidjeti vjerovnikovo pravo na „fiksni iznos" (engl. fixed sum; njem. Pauschalbetrag; fra. d'un montant forfaitaire) od najmanje četrdeset eura kao naknadu „troškova naplate“ (engl. recovery costs; njem. Beitreibungskosten; fra. frais de recouvrement) prouzročenih dužnikovim zakašnjenjem s plaćanjem. ${ }^{5}$

Naknada troškova naplate iz čl. 6. st. 1. Direktive 2011/7/EU je u naslovu čl. 13. ZFPPN-a nazvana je ,posebnom naknadom za troškove prouzročene vjerovniku dužnikovim zakašnjenjem s ispunjenjem novčane obveze u poslovnim transakcijama“. Zbog konciznosti, u daljnjem tekstu rada ona će se označavati „paušalnom naknadom troškova naplate“ (njem. Beitreibungskostenpauschale), a ponegdje i „paušalnom naknadom za zakašnjenje“" (njem. Verzugspauschale). ${ }^{6}$

$\mathrm{U}$ dostupnoj objavljenoj sudskoj praksi nisu pronađene odluke donesene $\mathrm{u}$ primjeni odredaba čl. 13. ZFPPN-a koje bi se podrobnije bavile pojedinim pitanjima u vezi s paušalnom naknadom troškova naplate na koja u ZFPPN-u nije dan izričit odgovor. U radu se raspravlja o nastanku obveze plaćanja paušalne naknade troškova naplate te njezinoj pravnoj prirodi i funkcijama, a nude se i odgovori na pitanja kada ona dospijeva te u kojemu roku zastarijeva. Odredbe ZFPPN-a tumače se sustavno

2 O određenju pojma ,poslovne transakcije“ u odredbi čl. 3. t. 16. ZFPPN-a vidi, primjerice: Ivan Tot, ,Novo posebno uređenje zateznih kamata - specifičnosti, polje primjene i usklađenost $\mathrm{s}$ pravnom stečevinom Europske unije“, Zbornik Pravnog fakulteta Sveučilišta u Rijeci 35, br. 1 (2014): 296-301.

3 O posebnoj naknadi iz odredbe čl. 13. st. 1. ZFPPN-a vidi, primjerice: Tea Hasić, „Rokovi ispunjenja novčanih obveza prema Zakonu o financijskom poslovanju i predstečajnoj nagodbi“, Zagrebačka pravna revija 3, br. 2 (2014): 204.

4 Direktiva 2011/7/EU Europskog parlamenta i Vijeća od 16. veljače 2011. o borbi protiv kašnjenja u plaćanju u poslovnim transakcijama, SL L 48, 23.2.2011. (dalje u tekstu: Direktiva 2011/7/EU).

5 O naknadi iz odredbe čl. 6. st. 1. Direktive 2011/7/EU vidi, primjerice: Tobias Oelsner, „Die Neufassung der Zahlungsverzugsrichtlinie“, EuZW - Europäische Zeitschrift für Wirtschaftsrecht 22, br. 24 (2011): 942; Tobias Oelsner, „Auswirkungen des Umsetzungsverzugs bei der Zahlungsverzugsrichtlinie“, NJW - Neue Juristische Wochenschrift 66, br. 34 (2013): 2471; Ivan Tot, „Pojam i pravne posljedice zakašnjenja s plaćanjem u trgovačkim ugovorima u pravu Europske unije“, Zbornik Pravnog fakulteta Sveučilišta u Rijeci 33, br. 2 (2012): 791-793.

6 Pod tim se skraćenim nazivima ona često susreće u njemačkoj pravnoj književnosti pa tako, primjerice, i u: Thomas Klein, „Ansprüche des Gläubigers bei Zahlungsverzug des Schuldners", JA - Juristische Arbeitsblätter 52, br. 1 (2020): 11; Hans Schulte-Nölke, „Verzugszinsen und sonstiger Verzugsschaden“, u: BGB - Schuldrecht - Band 2, ur. Barbara Dauner-Lieb i Werner Langen (Baden-Baden: Nomos Verlag, 2016.), § 288, Rn. 15; Michael Stöber i Georgios Petanidis, „Die Verzugspauschale nach § 288 Abs. 5 BGB im Lichte der EUZahlungsverzugsrichtlinie“, AGS - Anwaltsgebühren spezial 8, br. 1 (2017): 1. 
i teleološki, a iznesena tumačenja temelje se na poredbenopravnoj analizi, kao i na usklađenoj interpretaciji s Direktivom 2011/7/EU. Ona kao direktiva minimalne harmonizacije dopušta državama članicama zadržati ili donijeti odredbe nacionalnog prava koje bi za vjerovnike novčanih obveza bile povoljnije od odredaba koje je nužno donijeti radi usklađivanja s njom. ${ }^{7}$ Analizirani su propisi koji su doneseni radi transponiranja čl. 6. Direktive 2011/7/EU u svim državama članicama. ${ }^{8}$ Posebno su

$7 \quad$ Vidi odredbu čl. 12. st. 3. Direktive 2011/7/EU.

8 Za Republiku Austriju: Poduzetnički zakonik (Unternehmensgesetzbuch - Bundesgesetz über besondere zivilrechtliche Vorschriften für Unternehmen), Deutsches Reichsgesetzblatt, br. 23/1897., s posljednjom izmjenom od 23.7.2019., Bundesgesetzblatt, br. 22/15. (dalje u tekstu: austrijski UGB). Za Kraljevinu Belgiju: Zakon o borbi protiv zakašnjenja s plaćanjem u trgovačkim transakcijama (Loi concernant la lutte contre le retard de paiement dans les transactions commerciales), Moniteur belge, br. 247/02., s posljednjom izmjenom od 28.5.2019., Moniteur belge, br. 75/19. (dalje u tekstu: belgijski ZBPZP). Za Republiku Bugarsku: Trgovački zakon (Tărgovski zakon), Dăržaven vestnik, br. 48/91., s posljednjom izmjenom od 22.10.2019., Dăržaven vestnik, br. 83/19. (dalje u tekstu: bugarski TZ). Za Republiku Cipar: Zakon br. 123 o borbi protiv zakašnjenja s plaćanjem u trgovačkim transakcijama (Nómos n. 123 o Perí tis Katapolémisis ton Kathysteríseon Pliromón stis Emporikés Synallagés), Episimi Efimerida, br. 4349/12. (dalje u tekstu: ciparski ZBPZP). Za Češku Republiku: Građanski zakonik (Občanský zákoník), Sbírka zákonů, br. 33/12., s posljednjom izmjenom od 16.8.2018., Sbírka zákonů, br. 87/18. (dalje u tekstu: češki GZ) i Uredba Vlade br. 351/2013. (Nařizení vlády č. 351/2013) od 16. rujna 2013., Sbírka zákonů, br. 139/13. (dalje u tekstu: češka Uredba 351/2013). Za Kraljevinu Dansku: Zakon o kamatama i drugim pitanjima u slučaju zakašnjenja s plaćanjem (Lov om renter og andre forhold ved forsinket betaling (renteloven)), Lovtidende A, br. 743/02., s posljednjom izmjenom od 9.11.2015., Lovtidende A, br. 1237/15. (dalje u tekstu: danski ZK). Za Republiku Estoniju: Zakon o obligacijama (Võlaõigusseadus), Riigi Teataja I, br. 81/01., s posljednjom izmjenom od 14.12.2019. (dalje u tekstu: estonski ZOO). Za Republiku Finsku: Ovršni zakon (Laki saatavien perinnästä), Finlex, br. 513/99., s posljednjom izmjenom od 1.9.2019., Finlex, br. 598/19. (dalje u tekstu: finski OZ); Zakon o rokovima plaćanja u trgovačkim transakcijama (Laki kaupallisten sopimusten maksuehdoista), Finlex, br. 30/13., s posljednjom izmjenom od 15.4.2016., Finlex, br. 243/16. (dalje u tekstu: finski ZRP). Za Republiku Francusku: Trgovački zakonik (Code de commerce), Legifrance, pročišćeni tekst od 1.1.2020. (dalje u tekstu: francuski TZ); Dekret br. 2013-269 od 29. ožujka 2013. o borbi protiv zakašnjenja s plaćanjem u ugovorima o javnoj nabavi (Décret $n^{\circ}$ 2013-269 du 29 mars 2013 relatif à la lutte contre les retards de paiement dans les contrats de la commande publique), Journal Officiel de la République Française, br. 77/13. (dalje u tekstu: francuski Dekret 2013-269); Dekret br. 20181075 od 3. prosinca 2018. o regulatornom dijelu zakonika o javnoj nabavi (Décret $n^{\circ} 2018$ 1075 du 3 décembre 2018 portant partie réglementaire du code de la commande publique), Journal Officiel de la République Française, br. 281/18. (dalje u tekstu: francuski Dekret 20181075); Zakonik o javnoj nabavi (Code de la commande publique), Legifrance, pročišćeni tekst od 1.1.2020. (dalje u tekstu: francuski ZJN). Za Helensku Republiku: Zakon br. 4152/2013 o žurnoj implementaciji zakona 4046/2012, 4093/2012 i 4127/2013 (Nomos 4152/2013 Epeígonta métra efarmogís ton nómon 4046/2012, 4093/2012 kai 4127/2013), Efimerís tis Kyverníseos, br. 107/13. (dalje u tekstu: helenski Zakon 4152/2013). Za Republiku Irsku: Uredba o zakašnjenju s plaćanjem u trgovačkim transakcijama iz 2012. (European Communities (Late Payment in Commercial Transactions) Regulations 2012), Statutory Instrument, br. 580/12., s posljednjom izmjenom putem Uredbe iz 2016. (European Communities (Late Payment in Commercial Transactions) (Amendment) Regulations 2016), Statutory Instrument, br. 281/16. (dalje u tekstu: irska Uredba 580/2012). Za Talijansku Republiku: Zakonodavni dekret br. 231 
razmatrana stajališta austrijskog i njemačkoga prava kao hrvatskom pravu poredbenim

od 9. listopada 2002. o implementaciji Direktive 2000/35/EZ o borbi protiv kašnjenja u plaćanju u trgovačkim transakcijama (Decreto legislativo 9 ottobre 2002, n. 231, Attuazione della direttiva 2000/35/CE relativa alla lotta contro $i$ ritardi di pagamento nelle transazioni commerciali), Gazetta Ufficiale, br. 249/02., s posljednjom izmjenom od 30.10.2014., Gazetta Ufficiale, br. 261/14. (dalje u tekstu: talijanski ZD 231/2002). Za Republiku Latviju: Građanski zakonik (Civillikums), Valdības Vēstnesis, br. 41/37., s posljednjom izmjenom od 5.12.2019., Latvijas Vēstnesis, br. 246/19. (dalje u tekstu: latvijski GZ). Za Republiku Litvu: Zakon Republike Litve o sprječavanju zakašnjenja s plaćanjem u trgovačkim transakcijama (Lietuvos Respublikos mokejjimu, atliekamu pagal komercinius sandorius, vèlavimo prevencijos istatymo), Valstybės žinios, br. 127-6389/12. (dalje u tekstu: litavski ZSZP). Za Veliko Vojvodstvo Luksemburg: Zakon od 18. travnja 2004. o rokovima plaćanja i zateznim kamatama (Loi du 18 avril 2004 relative aux délais de paiement et aux intérêts de retard), Memorial A, br. 66/04., s posljednjom izmjenom od 29.3.2013., Memorial A, br. 67/13. (dalje u tekstu: luksemburški ZRPZK). Za Mađarsku: Zakon IX. iz 2016. o paušalnoj naknadi troškova naplate (2016. évi IX. törvény a behajtási költségátalányról), Magyar Közlöny, br. 39/16. (dalje u tekstu: mađarski ZPNTN). Za Republiku Maltu: Trgovački zakonik (Kodici tal-Kummerč / Commercial Code) od 2.10.1857., s posljednjom izmjenom od 17.1.2014., Government Gazette of Malta, br. 19,196/14. (dalje u tekstu: malteški TZ). Za Kraljevinu Nizozemsku: Građanski zakonik Knjiga 6 (Burgerlijk Wetboek Boek 6), s posljednjom izmjenom od 21.7.2019., Staatdsblad, br. 190/19. (dalje u tekstu: nizozemski BW-6). Za Saveznu Republiku Njemačku: Građanski zakonik (Bürgerliches Gesetzbuch in der Fassung der Bekanntmachung vom 2. Januar 2002), Bundesgesetzblatt I, br. 2/02., s posljednjom izmjenom od 21.12.2019., Bundesgesetzblatt I., br. 52/19. (dalje u tekstu: njemački BGB). Za Republiku Poljsku: Zakon od 8. ožujka 2013. o rokovima plaćanja u trgovačkim transakcijama (Ustawa z dnia 8 marca 2013 o terminach zaplaty $w$ transakcjach handlowych), Dziennik Ustaw, br. 403/13., s posljednjom izmjenom od 11.9.2019., Dziennik Ustaw, br. 2020/19. (dalje u tekstu: poljski ZRP). Za Republiku Portugal: Zakonodavni dekret br. 62/2013 (Decreto-Lei $n .^{\circ}$ 62/2013), Diário da República - Série I, br. 90/13. (dalje u tekstu: portugalski ZD 62/2013). Za Rumunjsku: Zakon br. 72/2013 o mjerama za borbu protiv zakašnjenja s plaćanjem (Legea nr. 72/2013 privind măsurile pentru combaterea întârzierii în executarea obligațiilor de plată a unor sume de bani rezultând din contracte încheiate intre profesioniști și între aceștia și autorități contractante), Monitorul Oficial, br. 182/13. (dalje u tekstu: rumunjski ZSZP). Za Slovačku Republiku: Trgovački zakonik (Obchodný zákonník), Zbierka zákonov, br. 98/91., s posljednjom izmjenom od 5.6.2019., Zbierka zákonov, br. 156/19. (dalje u tekstu: slovački TZ); Uredba Vlade Slovačke Republike o provedbi pojedinih odredbi Trgovačkog zakonika (Nariadenie vlády Slovenskej republiky, ktorým sa vykonávajú niektoré ustanovenia Obchodného zákonníka), Zbierka zákonov, br. 21/13. (dalje u tekstu: slovačka Uredba 21/2013). Za Republiku Sloveniju: Zakon o sprječavanju zakašnjenja s plaćanjem (Zakon o preprečevanju zamud pri plačilih), Uradni list, br. 57/12. (dalje u tekstu: slovenski ZPreZP). Za Kraljevinu Španjolsku: Zakon 3/2004 od 29. prosinca kojim se uspostavljaju mjere za borbu protiv zakašnjenja s plaćanjem u trgovačkim tranakcijama (Ley 3/2004, de 29 de diciembre, por la que se establecen medidas de lucha contra la morosidad en las operaciones comerciales), Boletín Oficial del Estado, br. 314/04., s posljednjom izmjenom od 30.9.2014., Boletín Oficial del Estado, br, 238/14. (dalje u tekstu: španjolski: ZBZP). Za Kraljevinu Švedsku: Zakon (1981: 739) o nadoknadi troškova naplate itd. (Lag (1981:739) om ersättning för inkassokostnader m.m.), Svensk författningssamling, br. 739/81., s posljednjom izmjenom od 14.2.2013., Svensk författningssamling, br. 56/13. (dalje u tekstu: švedski ZNTN). Za Ujedinjeno Kraljevstvo Velike Britanije i Sjeverne Irske: Zakon o zakašnjenju s plaćanjem trgovačkih dugova (o kamatama) (The Late Payment of Commercial Debts (Interest) Act 1998), UK Public General Acts, br. 20/98., s posljednjom izmjenom od 26.2.2018., UK Statutory Instruments, br. 117/18. (dalje u tekstu: ZZPTD). 
pravnim poredcima.

Rad je strukturiran u pet poglavlja. Nakon uvoda, u drugom se poglavlju raspravlja o nastanku vjerovnikova prava vjerovnika na paušalnu naknadu troškova naplate, a u trećem o njezinoj pravnoj prirodi i funkcijama. U četvrtom se poglavlju raspravlja o dospjelosti i zastari zahtjeva za paušalnom naknadom. Zaključci se iznose u posljednjem, petom poglavlju rada.

\section{NASTANAK PRAVA VJEROVNIKA NOVČANE OBVEZE NA PAUS̆ALNU NAKNADU TROŠKOVA NAPLATE}

Paušalna naknada troškova naplate iz odredbe čl. 13. st. 1. ZFPPN-a je posebna naknada koju od dužnika koji zakasni s ispunjenjem novčane obveze ima pravo zahtijevati vjerovnik novčane obveze u poslovnim transakcijama među poduzetnicima i u poslovnim transakcijama između poduzetnika i osobe javnog prava u kojima je ona dužnik novčane obveze. ${ }^{9}$ Vjerovnikovo pravo zahtijevati tu naknadu nastaje ex lege pa ga ugovorne strane u poslovnim transakcijama ne moraju posebno ugovarati. Osnova nastanka dužnikove obveze je sam zakon po čemu je paušalna naknada slična zateznim kamatama koje dužnik također duguje ex lege i prema općem uređenju sadržanom u Zakonu o obveznim odnosima ${ }^{10}$ i prema posebnom uređenju zateznih kamata sadržanom u ZFPPN-u. ${ }^{11}$ I druge su države članice pri transponiranju Direktive 2011/7/EU u nacionalno pravo predvidjele vjerovnikovo pravo na paušalnu naknadu kao njegovo ex lege pravo. ${ }^{12}$ Pritom su države članice koje pripadaju common law tradiciji posebno propisale da se dužnikova obveza plaćanja te naknade uzima kao implied term ugovora, kojim je nastala glavna novčana obveza s čijim je ispunjenjem dužnik pao u zakašnjenje. ${ }^{13}$

Za nastanak vjerovnikova prava na paušalnu naknadu iz odredbe čl. 13. st. 1.

9 Ali ne i u poslovnim transakcijama između poduzetnika i osobe javnog prava u kojima je poduzetnik dužnik novčane obveze. O polju primjene ZFPPN-a vidi: Tot, Novo posebno uređenje zateznih kamata, 286-301.

10 Zakon o obveznim odnosima, Narodne novine, br. 35/05., 41/08., 125/11., 78/15., 29/18. (dalje u tekstu: ZOO).

11 O zajedničkim obilježjima te ključnim razlikama općeg i posebnog uređenja zateznih kamata vidi: Ivan Tot, „Kamate“, u: Bankovni i financijski ugovori, red. Zvonimir Slakoper, ur. Maja Bukovac Puvača i Gabrijela Mihelčić (Zagreb: Narodne novine, 2017.), 137-144.

12 Vidi odredbe: § 458. austrijskog UGB-a; čl. 6. st. 1. belgijskog ZBPZP-a; čl. 309.a st. 1. bugarskog TZ-a; čl. 8. st. 1. ciparskog ZBPZP-a; § 3. češke Uredbe 351/2013; § 9.a st. 3. danskog ZK-a; § 113-1. st. 1. estonskog ZOO-a; § 10.e finskog OZ-a; čl. L441-10. st. II. francuskog TZa; čl. G.7. st. 1. helenskog Zakona 4152/2013; čl. 9. st. 1. irske Uredbe 580/2012; čl. 6. st. 2. talijanskog ZD 231/2002; čl. 1668-9. latvijskog GZ-a; čl. 7. st. 1. litavskog ZSZP-a; čl. 5. st. 1. luksemburškog ZRPZK-a; § 3. st. 1. mađarskog ZPNTN-a; čl. 26.E malteškog TZ-a; čl. 96. st. 4. nizozemskog BW-6; § 288. st. 5. njemačkog BGB-a; čl. 10. st. 1. poljskog ZRP-a; čl. 7. portugalskog ZD 62/2013; čl. 10. st. 1. rumunjskog ZSZP-a; § 369.c st. 1. slovačkog TZ-a; čl. 14. st. 1. slovenskog ZPreZP-a; čl. 8. st. 1. španjolskog ZBZP-a; § 4.a st. 1. švedskog ZNTN-a; čl. 5.A st. 1. ZZPTD-a za Ujedinjeno Kraljevstvo.

13 Za Ujedinjeno Kraljevstvo vidi odredbu čl. 5.A st. 3. ZZPTD-a, a za Republiku Irsku odredbu čl. 9. st. 1. irske Uredbe 580/2012. 
ZFPPN-a dostatno je da je dužnik pao u zakašnjenje s plaćanjem te nije potrebno ispunjavanje druge posebne pretpostavke. I po tome je paušalna naknada slična zateznim kamatama prema njihovu općem uređenju sadržanom u ZOO-u, ali se po tome ona ujedno i razlikuje od zateznih kamatama prema posebnom uređenju sadržanom u ZFPPN-u. Naime, prema odredbi čl. 12.a st. 1. ZFPPN-a, za nastanak vjerovnika prava na zatezne kamate potrebno je ispunjavanje i jedne dodatne pretpostavke: „da je vjerovnik ispunio svoje ugovorne i zakonske obveze“. ${ }^{14}$ Ta je odredba ZFPPN-a posljedica nespretnoga transponiranja odredaba čl. 3. st. 1. a) i čl. 4. st. 1. a) Direktive 2011/7/EU prema kojima se za nastanak vjerovnikova prava na zatezne kamate zahtijeva ispunjenje takve dodatne pretpostavke. Iz dijela odredbe čl. 6. st. 1 . Direktive 2011/7/EU, prema kojemu su države članice dužne osigurati vjerovnikovo pravo na paušalnu naknadu ,u slučajevima u kojima u skladu s čl. 3. ili 4. u poslovnim transakcijama nastaje obveza plaćanja zateznih kamata“, proizlazi da je i za nastanak obveze plaćanja paušalne naknade potrebno ispunjenje dodatne pretpostavke iz čl. 3. st. 1. a) i čl. 4. st. 1. a) Direktive 2011/7/EU. Okolnost da odredba čl. 13. st. 1. ZFPPN-a ne zahtijeva ispunjenje takve dodatne pretpostavke ne znači da bi zbog toga ona bila protivna zahtjevima Direktive 2011/7/EU. Naime, Direktiva 2011/7/ EU je po intenzitetu usklađivanja direktiva minimalne harmonizacije koja dopušta državama članicama zadržati ili donijeti odredbe koje su povoljnije za vjerovnike novčanih obveza. Budući da odredba čl. 13. st. 1. ZFPPN-a ne zahtijeva ispunjenje dodatnih pretpostavki za nastanak vjerovnikova prava na paušalnu naknadu, ona je $u$ tom pogledu povoljnija za vjerovnike novčanih obveza od odredaba Direktive 2011/7/ EU, pa je time i u skladu s njezinim zahtjevima.

Za nastanak vjerovnikova prava na paušalnu naknadu iz odredbe čl. 13. st. 1. ZFPPN-a ne zahtijeva se dužnikova odgovornost za zakašnjenje s plaćanjem. Dužnik duguje vjerovniku paušalnu naknadu neovisno o tome je li za zakašnjenje odgovoran, odnosno neovisno o svojoj krivnji za zakašnjenje s plaćanjem. Dakle, obveza plaćanja paušalne naknade objektivna je posljedica dužničkoga zakašnjenja s plaćanjem, jednako kao što je u hrvatskom pravu to i obveza plaćanja zateznih kamata. ${ }^{15} \mathrm{Za}$ razliku od hrvatskoga prava, prema Direktivi 2011/7/EU dužnikova je obveza plaćanja paušalne naknade subjektivna posljedica dužničkoga zakašnjenja s plaćanjem. To proizlazi iz odredbe čl. 6. st. 1. Direktive 2011/7/EU, a u vezi s odredbama čl. 3. st. 1. b) i čl. 4. st. 1. b) Direktive 2011/7/EU, prema kojima je za nastanak pravnih posljedica dužničkoga zakašnjenja s plaćanjem potrebno ispunjavanje i druge dodatne pretpostavke: da ,vjerovnik nije primio dospjeli iznos na vrijeme, osim ako dužnik nije odgovoran za zakašnjenje“ “. ${ }^{16}$ Budući da je objektivni koncept zakašnjenja $s$ plaćanjem za vjerovnike novčanih obveza povoljniji od subjektivnog koncepta, ni u ovom pogledu odredba čl. 13. st. 1. ZFPPN-a nije protivna Direktivi 2011/7/ EU kao direktivi minimalne harmonizacije. Po usvajanju objektivnoga koncepta zakašnjenja s plaćanjem u odredbi čl. 13. st. 1. ZFPPN-a, hrvatsko pravo blisko je

14 Za kritiku te odredbe vidi: Tot, Novo posebno uređenje zateznih kamata, 275-278.

15 Vidi o tomu: Tot, Kamate, 138-139.

16 O odredbama čl. 3. st. 1. b) i čl. 4. st. 1. b) Direktive 2011/7/EU vidi: Tot, Pojam i pravne posljedice zakašnjenja s plaćanjem u trgovačkim ugovorima u pravu Europske unije, 776-781. 
rješenjima austrijskog prava u kojemu je obveza plaćanja paušalne naknade također objektivna posljedica dužničkoga zakašnjenja s plaćanjem za čiji se nastanak ne zahtijeva dužnikova krivnja. ${ }^{17}$ Za razliku od hrvatskog i austrijskoga prava, u većini je drugih država članica pri transponiranju Direktive 2011/7/EU u nacionalno pravo obveza plaćanja paušalne naknade predviđena kao subjektivna posljedica dužničkoga zakašnjenja s plaćanjem, pa dužnik neće morati platiti paušalnu naknadu ako dokaže da za zakašnjenje nije odgovoran. ${ }^{18}$

Posebno je odredbom čl. 13. st. 1. ZFPPN-a istaknuto da vjerovnik novčane obveze ima pravo na paušalnu naknadu „,bez ikakve daljnje opomene“. U hrvatskom je pravu u odredbama čl. 183. st. 1. i 2. ZOO-a prihvaćeno načelo dies interpellat pro homine, prema kojemu rok ispunjenja obveze opominje sam po sebi. Stoga nije potrebno dužnika posebno opomenom ili na neki drugi način podsjećati na ispunjenje njegove obveze te će dužnik pasti u zakašnjenje čim ne ispuni obvezu u roku određenom za ispunjenje, a ne tek nakon što ga protekom tog roka vjerovnik pozove na ispunjenje obveze. U poslovnim transakcijama na koje se primjenjuje ZFPPN, ako rok ispunjenja novčane obveze nije određen ugovorom, dužnik je dužan novčanu obvezu ispuniti u zakonskim rokovima propisanim odredbama čl. 11. st. 3. i čl. 12. st. 3. ZFPPN-a. Budući da je u poslovnim transakcijama rok za ispunjenje novčane obveze uvijek „određen“ u smislu odredbe čl. 183. st. 1. ZOO-a, dužnik novčane obveze past će u zakašnjenje čim ju ne ispuni u ugovorenom ili zakonskom roku. Stoga je suvišno i isticanje da je on dužan ispuniti novčanu obvezu „bez potrebe da ga vjerovnik na to pozove" sadržano u odredbama čl. 11. st. 3. i čl. 12. st. 3. ZFPPN-a, kao $\mathrm{i}$ isticanje da za nastanak njegove obveze plaćanja paušalne naknade nije potrebna posebna opomena sadržano u odredbi čl. 13. st. 1. ZFPPN-a. To je isticanje posljedica transponiranja odredbe čl. 6. st. 2. Direktive 2011/7/EU, prema kojoj su države članice obvezne osigurati nastanak vjerovnikova prava na paušalnu naknadu ex lege, „bez potrebe slanja opomene“ dužniku novčane obveze. Pri transponiranju odredbe čl. 6. st. 2. Direktive 2011/7/EU u nacionalno pravo, druge su države članice većinom izričito predvidjele da vjerovnik ima pravo na paušalnu naknadu bez potrebe za opomenom. ${ }^{19} \mathrm{U}$ nacionalnim pravima država članica koje taj dio odredbe čl. 6. st.

17 Vidi odredbu § 458. austrijskog UGB-a, a u pravnoj književnosti, primjerice: Teresa Frizberg, „Entschädigung für Betreibungskosten“, u: UGB - Unternehmensgesetzbuch Kommentar, ur. Ulrich Torggler (Wien: Linde Verlag, 2013.), § 458., Rn. 2, 11; Thomas Haberer i Jörg Zehetner, „Das neue Zahlungsverzugsgesetz im Überblick“, Ecolex 4, br. 5 (2013): 412; Georgia Neumayer, „Das Zahlungsverzugsgesetz“, Zivilrecht aktuell 9, br. 10 (2013): 189. Obveza plaćanja paušalne naknade kao objektivna posljedica dužničkoga zakašnjenja s plaćanjem u poslovnim transakcijama predviđena je, primjerice, i u bugarskom pravu, odredbom čl. 309.a st. 1. bugarskog TZ-a.

18 Vidi, primjerice, odredbe: čl. 6. st. 1., u vezi s čl. 5. st. 1. belgijskog ZBPZP-a; čl. 8. st. 1., u vezi s čl. 5. st. 1. ciparskog ZBPZP-a; § 1968. i 1970. češkog GZ-a; § 9.a st. 1. danskog ZK-a; čl. G.7. st. 1., u vezi s čl. G.4. st. 1. i čl. G.5. st. 1. helenskog Zakona 4152/2013; čl. 6. st. 1., u vezi s čl. 3. st. 1. talijanskog ZD 231/2002; čl. 7. st. 1., u vezi s čl. 3. st. 1. litavskog ZSZP-a; čl. 5. st. 1., u vezi s čl. 3. st. 1. i čl. 4. st. 1. luksemburškog ZRPZK-a; čl. 26.E, u vezi s čl. 26.C st. 1. i čl. 26.D st. 1. malteškog TZ-a; § 288. st. 5., u vezi s § 286. st. 4. njemačkog BGB-a; čl. 10. st. 1., u vezi s čl. 7. st. 1. i čl. 8. st. 1. poljskog ZRP-a; čl. 8. st. 2. španjolskog ZBZP-a.

19 Vidi, primjerice, odredbe: čl. 6. st. 1. belgijskog ZBPZP-a; čl. 309.a st. 1. bugarskog TZ-a; 
2. Direktive 2011/7/EU nisu izrijekom transponirale, primjerice, u austrijskom pravu, istovjetno rješenje proizlazi iz općih pravila ugovornog prava. ${ }^{20}$

Vjerovnik ima pravo na paušalnu naknadu iz odredbe čl. 13. st. 1. ZFPPN-a neovisno o visini glavne novčane tražbine, pa i onda kada dužnik kasni s ispunjenjem novčane obveze $u$ iznosu nižemu od iznosa paušalne naknade. Vjerovnikovo pravo na paušalnu naknadu u iznosu iz odredbe čl. 13. st. 1. ZFPPN-a ne ovisi o trajanju dužničkoga zakašnjenja. Po tome se paušalna naknada kao pravna posljedica dužničkoga zakašnjenja s plaćanjem razlikuje od zateznih kamata koje se odmjeravaju pro rata temporis i u ovisnosti o visini glavne novčane tražbine.

Odredbom čl. 13. st. 1. ZFPPN-a vjerovnik novčane obveze je u slučaju dužničkoga zakašnjenja s plaćanjem ovlašten, no ne i obvezan zahtijevati od dužnika paušalnu naknadu. Istovjetno proizlazi i iz Direktive 2011/7/EU koja ne sadrži odredbu koja bi branila vjerovniku da se vlastitom voljom, nakon sklapanja ugovora kojim je nastala novčana obveza s čijim je ispunjenjem dužnik pao u zakašnjenje, odrekne svojega prava zahtijevati od dužnika isplatu paušalne naknade, što je potvrdio i Sud EU-a u predmetu IOS Finance. ${ }^{21}$

\section{PRAVNA PRIRODA I FUNKCIJE PAUS̆ALNE NAKNADE TROŠKOVA NAPLATE}

ZFPPN ne naziva izrijekom „posebnu naknadu“ iz odredbe čl. 13. st. 1. ZFPPN-a ,paušalnom“ naknadom. ${ }^{22} \mathrm{Za}$ razliku od ZFPPN-a, u propisima pojedinih drugih država članica već je u nazivu naknade istaknuto da je riječ o „paušalnoj“ naknadi, pa tako i u, primjerice, austrijskom, belgijskom, francuskom i njemačkom pravu. ${ }^{23}$ Službena inačica Direktive 2011/7/EU na hrvatskom jeziku, jednako kao i

čl. 8. st. 1. ciparskog ZBPZP-a; čl. G.7. st. 2. helenskog Zakona 4152/2013; čl. 9. st. 1. irske Uredbe 580/2012; čl. 6. st. 2. talijanskog ZD 231/2002; čl. 1668-9. latvijskog GZ-a; čl. 7. st. 1. litavskog ZSZP-a; čl. 5. st. 2. luksemburškog ZRPZK-a; čl. 26.E malteškog TZ-a; čl. 96. st. 4. nizozemskog BW-6; čl. 10. st. 1. poljskog ZRP-a; čl. 7. portugalskog ZD 62/2013; § 369.c st. 1. slovačkog TZ-a; čl. 8. st. 1. španjolskog ZBZP-a.

20 U austrijskom pravu, taj dio odredbe čl. 6. st. 2. Direktive 2011/7/EU nije izričito transponiran u odredbi § 458. austrijskog UGB-a, ali suvišnost slanja opomene dužniku koji svoju obvezu nije ispunio u roku određenom za ispunjenje proizlazi iz općih pravila sadržanih u $\S 1334$. austrijskog Općeg građanskog zakonika (Allgemeines bürgerliches Gesetzbuch für die gesammten deutschen Erbländer der Oesterreichischen Monarchie, Justizgesetzsammlung, br. 946/1811., s posljednjom izmjenom od 29.10.2019., Bundesgesetzblatt I, br. 105/19.; dalje u tekstu: ABGB). Za austrijsko pravo tako i: Frizberg, Entschädigung für Betreibungskosten, § 458., Rn. 6.

21 Presuda Suda EU-a od 16. veljače 2017., IOS Finance C-555/14, EU:C:2017:121, t. 30-34. Više o tom predmetu vidi u: Ivan Tot, „Late Payment Directive: Recent and Pending Cases at the Court of Justice", InterEULawEast 3, br. 2 (2016): 79-81.

22 U izvornoj inačici odredbe čl. 13. st. 1. ZFPPN-a iz 2012. (Narodne novine, br. 108/12.), bilo je istaknuto da je dužnik novčane obveze dužan vjerovniku platiti posebnu naknadu ,u paušalnom iznosu od 300,00 kuna“. Izraz ,paušalnom“ ispušten je pri izmjeni te odredbe u Zakonu o izmjenama i dopunama Zakona o financijskom poslovanju i predstečajnoj nagodbi, Narodne novine, br. 81/13. (dalje u tekstu: novela ZFPPN-a iz 2013.).

23 Usporedi nazive za tu naknadu upotrijebljene u odredbama: § 458. austrijskog UGB-a (njem. 
službena inačica na engleskom jeziku, u odredbi čl. 6. st. 1. govori o „fiksnom iznosu“ (engl. fixed sum), dok službene inačice na njemačkom, francuskom i talijanskom jeziku ističu da je riječ o paušalnom iznosu (njem. Pauschalbetrag; fra. d'un montant forfaitaire; tal. un importo forfettario).

Iz odredbe čl. 13. st. 2. ZFPPN-a, prema kojoj vjerovnik novčane obveze ima pravo na posebnu naknadu ,bez obzira na to je li pretrpio kakvu štetu zbog dužnikovog zakašnjenja“, nedvojbeno proizlazi da je riječ o naknadi u paušalnom iznosu. Vjerovnik ima pravo na nju i onda kada mu dužničkim zakašnjenjem nije prouzročena šteta, odnosno kada mu u povodu dužnikova zakašnjenja nisu nastali nikakvi dodatni troškovi. ${ }^{24}$ On nije dužan dokazati da mu je zakašnjenje s plaćanjem prouzrokovalo troškove, ${ }^{25}$ već se po zakonu pretpostavlja da su mu prouzročeni troškovi najmanje u visini koja odgovara iznosu paušalne naknade iz odredbe čl. 13. st. 1. ZFPPN-a.

Premda je u naslovu čl. 13. ZFPPN-a istaknuto da je riječ o posebnoj naknadi za „troškove prouzročene vjerovniku dužnikovim zakašnjenjem“, u odredbama čl. 13. ZFPPN-a nije pobliže opisano za koje vjerovnikove troškove je ona namijenjena. U poredbenom pravu u pravilu se ističe da je riječ o naknadi za vjerovnikove ,troškove naplate", ali također bez pobližeg navođenja pojedinih troškova naplate na koje se ona odnosi. ${ }^{26}$ I u odredbi čl. 6. st. 2. Direktive 2011/7/EU istaknuto je samo da je paušalni iznos „naknada za vjerovnikove vlastite troškove naplate“ (engl. compensation for the creditor's own recovery costs; njem. Entschädigung für die Beitreibungskosten des Gläubigers). Svrha je te naknade jasnije pojašnjena u t. 19. preambule Direktive 2011/7/EU prema kojoj je ona namijenjena pokriću vjerovnikovih administrativnih i internih troškova povezanih s naplatom tražbine. Takvi su, primjerice, troškovi izrade

Pauschalbetrag); § 288. st. 5. njemačkog BGB-a (njem. Pauschale); čl. 6. st. 1. belgijskog ZBPZP-a i čl. L441-10. st. II. francuskog TZ-a (fra. d'une indemnité forfaitaire).

24 Tako i za austrijsko pravo: Frizberg, Entschädigung für Betreibungskosten, § 458., Rn. 2-3; Haberer i Zehetner, Das neue Zahlungsverzugsgesetz im Überblick, 412; Neumayer, Das Zahlungsverzugsgesetz, 189. Tako i za njemačko pravo: Tim W. Dornis, „Die Entschädigungspauschale für Beitreibungsaufwand - Neujustierung von Kompensation und Prävention im europäischen und deutschen Verzugsrecht?", WM - Wertpapier-Mitteilungen 68, br. 15 (2014): 678; Tim W. Dornis, „Vom künftigen Umgang mit einer Unbekannten - die „Entschädigungspauschale“ im neuen $\S 288$ BGB“, ZIP - Zeitschrift für Wirtschaftsrecht 34, br. 50 (2014): 2429; Oelsner, Die Neufassung der Zahlungsverzugsrichtlinie, 942; SchulteNölke, Verzugszinsen und sonstiger Verzugsschaden, Rn. 16; Astrid Stadler, „Verzugszinsen und sonstiger Verzugsschaden“, u: Jauernig - Bürgerliches Gesetzbuch - Kommentar, ur. Rolf Stürner (München: C.H. Beck, 2018.), § 288, Rn. 11; Stöber i Petanidis, Die Verzugspauschale nach $\S 288$ Abs. 5 BGB im Lichte der EU-Zahlungsverzugsrichtlinie, 2; Dirk A. Verse, „Das Gesetz zur Bekämpfung von Zahlungsverzug im Geschäftsverkehr“, ZIP - Zeitschrift für Wirtschaftsrecht 34, br. 38 (2014): 1816; Marc-Philippe Weller i Charlotte Sophie Harms, „Die Kultur der Zahlungstreue im BGB - Zur Umsetzung der neuen EU-Zahlungsverzugsrichtlinie ins deutsche Recht", WM - Wertpapier-Mitteilungen 66, br. 49 (2012): 2312.

25 Izričita odredba o tome sadržana je, primjerice, u irskom pravu u čl. 9. st. 2. irske Uredbe 580/2012.

26 Usporedi odredbe: § 458. austrijskog UGB-a; čl. 6. st. 1. belgijskog ZBPZP-a; čl. 309.a st. 1. bugarskog TZ-a; čl. 8. st. 1. ciparskog ZBPZP-a; § 9.a st. 3. danskog ZK-a; § 113-1. st. 1. estonskog ZOO-a; čl. L441-10. st. II. francuskog TZ-a; čl. G.7. st. 2. helenskog Zakona 4152/2013; čl. 9. st. 1. irske Uredbe 580/2012. 
opomena slanih dužniku, poštanski troškovi slanja opomena, troškovi uredskog materijala, troškovi telefonskih razgovora kojima se dužnika pozivalo na plaćanje dužne novčane obveze i sl. ${ }^{27}$

Odredbom čl. 6. st. 3. Direktive 2011/7/EU, države članice obvezne su osigurati da vjerovnik novčane obveze uz paušalnu naknadu iz odredbe čl. 6. st. 1. Direktive 2011/7/EU ima pravo i na ,razumnu naknadu“ (engl. reasonable compensation; njem. angemessenen Ersatz) troškova naplate koji su mu prouzročeni dužničkim zakašnjenjem s plaćanjem, a čiji iznos prelazi iznos paušalne naknade. „Razumna naknada“ iz odredbe čl. 6. st. 3. Direktive 2011/7/EU namijenjena je i pokriću vjerovnikovih troškova naplate koji nisu administrativni i interni troškovi u smislu t. 19. preambule i pokriću administrativnih i internih troškova koje vjerovnik nije namirio iz iznosa paušalne naknade. ${ }^{28}$ Dok je paušalna naknada $u$ funkciji nadoknade pretpostavljene štete, „razumna naknada“ ima funkciju nadoknade stvarne štete. Odredbe ZFPPN-a ne spominju izričito pravo na „razumnu naknadu“, no vjerovnik pravo na naknadu troškova naplate koji premašuju iznos paušalne naknade može zahtijevati prema odredbi čl. 342. st. 2. ZOO-a, odnosno prema općim pravilima o ugovornoj odgovornosti za štetu zbog zakašnjenja.

Paušalna je naknada troškova naplate iz odredbe čl. 13. st. 1. ZFPPN-a apstraktna, zakonska naknada pretpostavljene štete prouzročene vjerovniku dužnikovim zakašnjenjem s plaćanjem, a njezina je primarna funkcija nadoknada dijela vjerovnikovih administrativnih $\mathrm{i}$ internih troškova povezanih $\mathrm{s}$ naplatom tražbine. ${ }^{29}$ Pored odštetne funkcije, paušalna naknada troškova naplate ima i kaznenu funkciju jer vjerovnik novčane obveze ima pravo na nju neovisno o tome je li pretrpio kakvu štetu zbog dužničkoga zakašnjenja. Obvezi njezina plaćanja dužnik se ne može suprotstaviti argumentom da vjerovniku nisu prouzročeni nikakvi troškovi naplate niti da su mu prouzročeni troškovi u nižem iznosu od iznosa paušalne naknade. ${ }^{30}$ Međutim, to ne znači da je paušalna naknada iz čl. 13. st. 1. ZFPPN-a retributivna sankcija. Njezina svrha u tom kontekstu nije retribucija, već prevencija te je njezin

27 Tot, Pojam i pravne posljedice zakašnjenja s plaćanjem u trgovačkim ugovorima u pravu Europske unije, 792.

28 Usporedi: Tot, Pojam i pravne posljedice zakašnjenja s plaćanjem u trgovačkim ugovorima u pravu Europske unije, 793-794. O razlikama vjerovnikovih internih i ostalih troškova naplate te o odnosu paušalne naknade iz čl. 6. st. 1. Direktive 2011/7/EU i razumne naknade iz čl. 6. st. 3. Direktive 2011/7/EU.

29 U istom smislu i: Hasić, Rokovi ispunjenja novčanih obveza prema Zakonu o financijskom poslovanju i predstečajnoj nagodbi, 204. U istom smislu za naknadu iz čl. 6. st. 1. Direktive 2011/7/EU i §288. st. 5.njemačkog BGB-a:Klein, Ansprüche des Gläubigers bei Zahlungsverzug des Schuldners, 11; Schulte-Nölke, Verzugszinsen und sonstiger Verzugsschaden, § 288, Rn. 16; Weller i Harms, Die Kultur der Zahlungstreue im BGB - Zur Umsetzung der neuen EUZahlungsverzugsrichtlinie ins deutsche Recht, 2312; Tot, Pojam i pravne posljedice zakašnjenja s plaćanjem u trgovačkim ugovorima u pravu Europske unije, 792.

30 U njemačkoj pravnoj književnosti često se ističe da paušalna naknada iz odredbe $\S 288$. st. 5. njemačkog BGB-a ima karakter penala pa tako i: Wolfgang Ernst, „Verzugszinsen und sonstiger Verzugsschaden“, u: Münchener Kommentar zum Bürgerlichen Gesetzbuch - Band 2 - Schuldrecht-Allgemeiner Teil I, ur. Wolfgang Krüger (München: C.H. Beck, 2019.), § 288, Rn. 30; Schulte-Nölke, Verzugszinsen und sonstiger Verzugsschaden, § 288, Rn. 16; Weller i Harms, Die Kultur der Zahlungstreue im BGB, 2312. 
cilj odvratiti dužnike novčanih obveza od zakašnjenja s plaćanjem i potaknuti ih na pravodobno ispunjavanje novčanih obveza. ${ }^{31}$

\section{DOSPJELOST I ZASTARA ZAHTJEVA ZA ISPLATOM PAUS̆ALNE NAKNADE TROŠKOVA NAPLATE}

Odredbe ZFPPN-a ne bave se izričito pitanjem trenutka dospijeća paušalne naknade iz odredbe čl. 13. st. 1. ZFPPN-a. Budući da je riječ o apstraktnoj, paušalnoj naknadi na koju vjerovnik ima pravo ex lege ako je dužnik pao u zakašnjenje $\mathrm{s}$ plaćanjem, a da za to nije potrebno ispunjenje kakve dodatne pretpostavke, a posebno da nije potrebno da vjerovnik pozove dužnika na plaćanje te naknade opomenom ili na koji drugi način, zaključuje se da obveza plaćanja paušalne naknade dospijeva danom dužnikova pada u zakašnjenje s plaćanjem, odnosno prvog dana nakon isteka ugovorom ili zakonom određenog roka za ispunjenje glavne novčane obveze. ${ }^{32}$ To proizlazi i iz usklađene interpretacije s odredbom čl. 6. st. 1. Direktive 2011/7/EU, prema kojoj države članice moraju osigurati da je vjerovnik ovlašten na paušalnu naknadu onda kada „dospijevaju zatezne kamate“, što u kontekstu hrvatskoga prava znači ex lege u trenutku dužnikova pada u zakašnjenje s plaćanjem.

U poslovnim transakcijama u kojima je ugovorena obročna otplata, vjerovnik prema odredbi čl. 14.a ZFPPN-a ima pravo zahtijevati plaćanje paušalne naknade iz čl. 13. st. 1. ZFPPN-a za svaki obrok s čijim plaćanjem dužnik padne u zakašnjenje. Takvom zakonskom rješenju može se prigovoriti da ono dovodi u nepovoljniji položaj dužnika koji padne u zakašnjenje s plaćanjem više pojedinih obroka u odnosu na dužnika koji padne u zakašnjenje s plaćanjem po ukupnom iznosu istovjetne glavne novčane obveze koju se obvezao jednokratno ispuniti vjerovniku. Međutim, ono je u skladu s odredbama Direktive 2011/7/EU koje se odnose na obročnu otplatu. Naime, prema odredbi čl. 5. Direktive 2011/7/EU, u slučaju ugovorene obročne otplate, zatezne kamate i „naknada predviđena u Direktivi“ obračunavaju se „,isključivo na temelju dospjelih iznosa“. Budući da se zatezne kamate obračunavaju u ovisnosti o visini iznosa dospjele novčane obveze, nema dvojbe o ispravnosti rješenja predviđenoga Direktivom 2011/7/EU o obračunavanju zateznih kamata zasebno na pojedine dospjele obroke. S druge strane, iznos paušalne naknade ne ovisi o

31 U istom smislu u kontekstu Direktive 2011/7/EU: Tot, Pojam i pravne posljedice zakašnjenja s plaćanjem u trgovačkim ugovorima u pravu Europske unije, 793. Za austrijsko pravo, tako i: Frizberg, Entschädigung für Betreibungskosten, § 458, Rn. 1. Za njemačko pravo, tako i: Dornis, Die Entschädigungspauschale für Beitreibungsaufwand, 678-679; Klein, Ansprüche des Gläubigers bei Zahlungsverzug des Schuldners, 11; Schulte-Nölke, Verzugszinsen und sonstiger Verzugsschaden, § 288, Rn. 11.

32 Usporedivo je rješenje prihvaćeno u nizozemskom pravu, u kojemu je odredbom čl. 96. st. 4. BW6. određeno da paušalna naknada dospijeva prvi dan nakon isteka roka za plaćanje. Istovjetno se dan dospijeća paušalne naknade tumači i u austrijskoj pravnoj književnosti, pa tako i: Frizberg, Entschädigung für Betreibungskosten, § 458, Rn. 5. Istovjetno i za njemačko pravo: Ernst, Verzugszinsen und sonstiger Verzugsschaden, § 288, Rn. 33; Schulte-Nölke, Verzugszinsen und sonstiger Verzugsschaden, § 288, Rn. 16; Stadler, Verzugszinsen und sonstiger Verzugsschaden, $\S 288$, Rn. 11; Verse, Das Gesetz zur Bekämpfung von Zahlungsverzug im Geschäftsverkehr, 1816; Weller i Harms, Die Kultur der Zahlungstrene im BGB, 2312. 
visini glavne novčane tražbine pa nije sasvim jasno što bi to značilo da je u slučaju ugovorene obročne otplate i paušalnu naknadu potrebno obračunavati ,isključivo na temelju dospjelih iznosa“. Jedno je tumačenje da bi i iznos paušalne naknade trebalo raspodijeliti na pojedine obroke u razmjeru koji odgovara odnosu iznosa pojedinog obroka prema ukupnom iznosu dugovane tražbine. ${ }^{33}$ Prihvaćanju toga tumačenja protive se svrha i funkcije naknade iz čl. 6. st. 1. Direktive 2011/7/EU kao paušalne naknade pretpostavljene štete prouzročene dužničkim zakašnjenjem. ${ }^{34}$ Prihvatljivije je tumačenje odredbe čl. 5. Direktive 2011/7/EU ono prema kojemu je dužnik obvezan platiti paušalnu naknadu zasebno za svaki obrok s čijim plaćanjem padne u zakašnjenje, jer je ono povoljnije za vjerovnike novčanih obveza čijoj je zaštiti od negativnih učinaka zakašnjenja s plaćanjem Direktiva 2011/7/EU i namijenjena. Takvo tumačenje odredbe čl. 5. Direktive 2011/7/EU prihvaćeno je i pri njezinom transponiranju u nacionalna prava drugih država članica koje su predvidjele rješenja, usporediva s odredbom čl. 14.a ZFPPN-a, prema kojima vjerovnik ima pravo na paušalnu naknadu za svaki obrok s čijim plaćanjem dužnik padne u zakašnjenje. ${ }^{35}$

Vjerovnikovo pravo na paušalnu naknadu ne isključuje niti na bilo koji način ograničava njegovo pravo na zatezne kamate. ${ }^{36}$ To proizlazi i iz odredbe čl. 13. st. 3. ZFPPN-a, prema kojoj vjerovnikovo pravo na paušalnu naknadu ne umanjuje, ograničava niti isključuje ,ostala prava koja mu pripadaju zbog dužnikovog zakašnjenja“ i iz odredbe čl. 6. st. 1. Direktive 2011/7/EU, kao i iz t. 19. preambule Direktive 2011/7/EU u kojoj je istaknuto da je paušalnu naknadu troškova naplate moguće kumulirati sa zateznim kamatama.

Suprotno stajalištu izraženom u obrazloženju prijedloga novele ZFPPN-a iz 2013., ${ }^{37}$ za hrvatsko pravo valja prihvatiti da vjerovnik ima pravo zahtijevati i plaćanje zateznih kamata obračunatih na iznos paušalne naknade iz odredbe čl. 13. st. 1. ZFPPN-a ako dužnik padne u zakašnjenje s plaćanjem te paušalne naknade. ${ }^{38}$ On u to zakašnjenje pada ako paušalna naknada nije plaćena vjerovniku o njezinu dospijeću, tj. prvoga dana po isteku roka određenog za ispunjenje glavne novčane obveze. Budući da su zatezne kamate u hrvatskom pravu objektivna posljedica dužničkoga zakašnjenja s ispunjenjem bilo koje novčane obveze, vjerovnik ima pravo

33 Vidi o tom tumačenju u: Weller i Harms, Die Kultur der Zahlungstreue im BGB, 2313.

34 U istom smislu i: Weller i Harms, Die Kultur der Zahlungstreue im BGB, 2313.

35 Usporedi, primjerice, odredbe: čl. 4. st. 3. belgijskog ZBPZP-a; čl. 309.a st. 1. bugarskog TZ-a; čl. 7. ciparskog ZBPZP-a; čl. 8. litavskog ZSZP-a; čl. 26.F malteškog TZ-a; $§ 288$. st. 5. njemačkog BGB-a; čl. 6. portugalskog ZD 62/2013. U njemačkoj pravnoj književnosti za istovjetno tumačenje odredbe $\S 288$. st. 5. njemačkog BGB-a vidi, primjerice: Ernst, Verzugszinsen und sonstiger Verzugsschaden, § 288, Rn. 33; Verse, Das Gesetz zur Bekämpfung von Zahlungsverzug im Geschäftsverkehr, 1816.

36 Tako i za njemačko pravo: Ernst, Verzugszinsen und sonstiger Verzugsschaden, § 288, Rn. 39; Klein, Ansprüche des Gläubigers bei Zahlungsverzug des Schuldners, 12.

37 U obrazloženju prijedloga čl. 7. novele ZFPPN-a iz 2013. navodi se: „Posebna naknada je fiksni iznos... na koji se ne plaća porez niti kamate.“ (Prijedlog Zakona o izmjenama i dopunama Zakona o financijskom poslovanju i predstečajnoj nagodbi, s konačnim prijedlogom Zakona, predlagatelja Vlade Republike Hrvatske, 20.6.2013., P.Z.E. br. 413, 41; dalje u tekstu: Prijedlog novele ZFPPN-a iz 2013.).

38 Tako i za njemačko pravo: Ernst, Verzugszinsen und sonstiger Verzugsschaden, § 288, Rn. 36. 
zahtijevati i zatezne kamate koje teku na iznos neplaćene paušalne naknade. Paušalna naknada troškova naplate nema funkcije koje bi bile istovjetne funkcijama zateznih kamata. ${ }^{39}$ Stoga u ovom kontekstu nije opravdano niti analogijom primijeniti čl. 31 . ZOO-a o zabrani anatocizma.

Padne li dužnik u zakašnjenje s plaćanjem paušalne naknade, vjerovnik nema pravo zahtijevati dodatnu paušalnu naknadu troškova naplate prouzročenih zakašnjenjem s plaćanjem paušalne naknade. ${ }^{40}$ Naime, vjerovnikovo pravo na paušalnu naknadu iz odredbe čl. 13. st. 1. ZFPPN-a, kao posebnu naknadu za troškove prouzročene dužnikovim zakašnjenjem $\mathrm{s}$ ispunjenjem ,novčane obveze u poslovnim transakcijama“, nastaje samo u slučaju dužnikova zakašnjenja s ispunjenjem glavne novčane obveze koja je protučinidba vjerovnikovoj nenovčanoj obvezi. To proizlazi iz odredbe čl. 13. st. 1. ZFPPN-a u vezi s odredbom čl. 3. t. 5. ZFPPN-a, koja određuje pojam „novčane obveze“ kao „iznos glavnice koji je trebao biti plaćen u roku predviđenom ugovorom ili zakonom", te u vezi s odredbom čl. 3.t. 16. ZFPPN-a kojom su „poslovne transakcije“ definirane kao transakcije koje „rezultiraju dobavom robe ili pružanjem usluga za novčanu naknadu“. Ovo je tumačenje u skladu i s Direktivom 2011/7/EU koja se, prema odredbi čl. 1. st. 2. Direktive 2011/7/EU, primjenjuje na „sva plaćanja na ime naknade u poslovnim transakcijama“" (engl. all payments made as remuneration for commercial transactions; njem. alle Zahlungen, die als Entgelt im Geschäftsverkehr zu leisten sind).

Odredbe ZFPPN-a, kao ni odredbe Direktive 2011/7/EU, ne uređuju rok u kojemu zastarijeva vjerovnikov zahtjev za plaćanjem iznosa paušalne naknade iz odredbe čl. 13. st. 1. ZFPPN-a. Budući da je riječ o naknadi pretpostavljene štete prouzročene zakašnjenjem $\mathrm{s}$ ispunjenjem ugovorne obveze, analogijom je potrebno primijeniti odredbu čl. 230. st. 3. ZOO-a. Stoga zahtjev za isplatom paušalne naknade zastarijeva u roku koji je određen za zastaru zahtjeva za ispunjenjem glavne novčane obveze s kojom je dužnik pao u zakašnjenje. Zbog toga što poslovne transakcije u smislu ZFPPN-a u pravilu odgovaraju ,trgovačkim ugovorima o prometu robe i usluga“ $u$ smislu odredbe čl. 228. st. 1. ZOO, u pravilu će zahtjev za paušalnom naknadom zastarijevati u posebnom zastarnom roku od tri godine, no do primjene može doći i opći zastarni rok iz čl. 225. ZOO-a u onim poslovnim transakcijama koje se ne podudaraju s pojmom trgovačkih ugovora. ${ }^{41}$ Tražbina na isplatu paušalne naknade nije ,povremena tražbina“ u smislu čl. 226. st. 1. ZOO-a. Ona je sporedna tražbina u smislu odredbe čl. 223. ZOO-a, stoga zastarijeva kada zastari i glavna novčana tražbina. ${ }^{42}$ I druge države članice u pravilu nisu u nacionalnom pravu posebno uredile

39 Zatezne kamate nisu naknada štete te nemaju odštetnu funkciju. Zatezne kamate imaju nadoknadnu i kaznenu funkciju u kojoj su sjedinjeni i elementi retribucije i prevencije. Vidi o tome: Tot, Kamate, 144-146.

40 Tako i za njemačko pravo: Ernst, Verzugszinsen und sonstiger Verzugsschaden, § 288, Rn. 31, 36; Stadler, Verzugszinsen und sonstiger Verzugsschaden, § 288, Rn. 11; Stöber i Petanidis, Die Verzugspauschale nach $\$ 288 \mathrm{Abs} .5 \mathrm{BGB}$ im Lichte der EU-Zahlungsverzugsrichtlinie, 3.

41 Za razgraničenje pojma ,poslovne transakcije“ iz ZFPPN-a i pojmova „trgovački ugovori“ i „,ugovori između trgovca i osobe javnog prava“" iz ZOO-a vidi: Tot, Novo posebno uređenje zateznih kamata, 298-301.

42 U njemačkom se pravu paušalna naknada iz odredbe § 286. st. 5. njemačkoga BGB-a smatra 
pitanje zastare tražbine za isplatom paušalne naknade troškova naplate pa će biti primjenjiva opća pravila o zastari. Iznimka je mađarsko i slovensko pravo u kojima su propisani i posebni rokovi zastare te tražbine. ${ }^{43}$

\section{ZAKLJUČAK}

Posebna naknada za troškove prouzročene vjerovniku dužnikovim zakašnjenjem $\mathrm{s}$ ispunjenjem novčane obveze u poslovnim transakcijama iz odredbe čl. 13. st. 1. ZFPPN-a nova je pravna posljedica zakašnjenja s plaćanjem u hrvatskom pravu, a na nju imaju pravo vjerovnici novčanih obveza u tzv. poslovnim transakcijama koje ulaze u polje primjene ZFPPN-a. Ta paušalna naknada za zakašnjenje s plaćanjem u hrvatsko je pravo uvedena pri transponiranju odredaba čl. 6. Direktive 2011/7/EU, a one su donesene po uzoru na prethodna rješenja sadržana u pravu Republike Irske i Ujedinjenog Kraljevstva, dviju država članica koje pripadaju common law tradiciji.

Vjerovnikovo pravo na paušalnu naknadu iz odredbe čl. 13. st. 1. ZFPPN-a nastaje ex lege te ga ugovorne strane ne moraju posebno ugovarati. Za nastanak toga prava dostatno je da je dužnik pao u zakašnjenje s plaćanjem te se ne zahtijeva ispunjavanje nikakve dodatne zakonske pretpostavke. Obveza plaćanja paušalne naknade objektivna je posljedica dužničkoga zakašnjenja s plaćanjem. Vjerovnikovo pravo na paušalnu naknadu neovisno je i o iznosu glavnoga duga i o trajanju dužničkoga zakašnjenja, po čemu se ova pravna posljedica zakašnjenja s plaćanjem razlikuje od zateznih kamata koje se odmjeravaju pro rata temporis i u ovisnosti o iznosu glavnog duga.

Vjerovnik novčane obveze u poslovnim transakcijama ima pravo na paušalnu naknadu troškova naplate neovisno o tome jesu li mu dužnikovim zakašnjenjem $s$ plaćanjem prouzročeni kakvi troškovi te nije dužan dokazivati da su mu prouzročeni troškovi u iznosu koji odgovara iznosu paušalne naknade. Paušalna naknada troškova naplate je zakonska naknada pretpostavljene štete prouzročene vjerovniku dužničkim zakašnjenjem s plaćanjem. Njezina je primarna funkcija nadoknada dijela vjerovnikovih administrativnih i internih troškova povezanih s naplatom tražbine, a takvi su, primjerice, troškovi opomena slanih dužniku. Pored odštetne funkcije, ona ima i kaznenu funkciju koja se iscrpljuje u elementima prevencije. Paušalna naknada ne sadrži elemente retribucije te u tom pogledu nije riječ o privatnopravnoj sankciji čija svrha bi bila kažnjavanje dužnika novčanih obveza. Njezin je cilj odvratiti dužnike novčanih obveza od zakašnjenja s plaćanjem i potaknuti ih na pravovremeno ispunjenje novčanih obveza.

Obveza plaćanja paušalne naknade za zakašnjenje s plaćanjem dospijeva

sporednom tražbinom pa zahtjev za njezinom isplatom zastarijeva, u skladu s odredbom $§ 217$. BGB-a, kada zastari i glavna tražbina. Na zastaru toga zahtjeva primjenjuje se opći zastarni rok od tri godine u skladu s odredbom $\S 195$. BGB-a. Vidi o tome u: Ernst, Verzugszinsen und sonstiger Verzugsschaden, § 288, Rn. 48.

43 U mađarskom pravu, prema odredbi § 3. st. 2. ZPNTN-a, tražbina za isplatu paušalne naknade zastarijeva u roku od godine dana od dana zakašnjenja s plaćanjem. U slovenskom je pravu odredbom čl. 14. st. 4. ZPreZP-a propisan posebni zastarni rok te tražbine od tri godine od dana zakašnjenja s plaćanjem. 
danom dužnikovog pada u zakašnjenje s plaćanjem, odnosno prvog dana nakon isteka ugovorom ili zakonom određenog roka za ispunjenje glavne novčane obveze. Kod ugovorene obročne otplate glavne novčane obveze, vjerovnik ima pravo zahtijevati paušalnu naknadu za svaki obrok s čijim plaćanjem dužnik padne u zakašnjenje. Zakasni li dužnik i s plaćanjem paušalne naknade, vjerovnik ima pravo zahtijevati plaćanje zateznih kamata obračunatih na iznos paušalne naknade, no nema pravo i na novu dodatnu paušalnu naknadu. Zahtjev za isplatom paušalne naknade zastarijeva u roku koji je određen za zastaru zahtjeva za ispunjenjem glavne novčane obveze s kojom je dužnik pao u zakašnjenje. Tražbina na isplatu paušalne naknade je sporedna tražbina koja zastarijeva kada zastari i glavna novčana tražbina.

U radu se nije raspravilo pitanje dopuštenosti ugovaranja paušalne naknade u iznosu različitom od iznosa iz čl. 13. st. 1. ZFPPN-a, kao ni odnos vjerovnikova zahtjeva za isplatom paušalne naknade i njegova zahtjeva za naknadom štete zbog dužničkoga zakašnjenja. Ta pitanja ostavljaju se za nastavak istraživanja.

\section{LITERATURA}

Knjige i poglavlja u knjizi:

1. Ernst, Wolfgang. „Verzugszinsen und sonstiger Verzugsschaden“. U: Münchener Kommentar zum Bürgerlichen Gesetzbuch - Band 2 - Schuldrecht - Allgemeiner Teil I, Hrsg. Wolfgang Krüger, § 288, Rn. 1-48. München: C.H. Beck, 2019.

2. Frizberg, Teresa. „Entschädigung für Betreibungskosten“. U: UGB Unternehmensgesetzbuch Kommentar, Hrsg. Ulrich Torggler, § 458, Rn. 1-14. Wien: Linde Verlag, 2013.

3. Schulte-Nölke, Hans. „Verzugszinsen und sonstiger Verzugsschaden“. U: $B G B$ Schuldrecht - Band 2, Hrsg. Barbara Dauner-Lieb i Werner Langen, § 288, Rn. 1-26. Baden-Baden: Nomos Verlag, 2016.

4. Stadler, Astrid. „Verzugszinsen und sonstiger Verzugsschaden“. U: Jauernig - Bürgerliches Gesetzbuch - Kommentar, Hrsg. Rolf Stürner, § 288, Rn 1-12. München: C.H. Beck, 2018.

5. Tot, Ivan. „Kamate“. U: Bankovni i financijski ugovori, red. Zvonimir Slakoper, ur. Maja Bukovac Puvača i Gabrijela Mihelčić, 93-186. Zagreb: Narodne novine, 2017.

Članci u časopisima:

1. Dornis, Tim W. „Die Entschädigungspauschale für Beitreibungsaufwand - Neujustierung von Kompensation und Prävention im europäischen und deutschen Verzugsrecht?“. WM - Wertpapier-Mitteilungen 68, br. 15 (2014): 677-682.

2. Dornis, Tim W. „Vom künftigen Umgang mit einer Unbekannten - die „Entschädigungspauschale“ im neuen § 288 BGB“. ZIP - Zeitschrift für Wirtschaftsrecht 34, br. 50 (2014): 2427-2434.

3. Haberer, Thomas i Zehetner, Jörg. „Das neue Zahlungsverzugsgesetz im Überblick“. Ecolex 4, br. 5 (2013): 406-413.

4. Hasić, Tea. „Rokovi ispunjenja novčanih obveza prema Zakonu o financijskom poslovanju i predstečajnoj nagodbi“. Zagrebačka pravna revija 3, br. 2 (2014): 195-212.

5. Klein, Thomas. „Ansprüche des Gläubigers bei Zahlungsverzug des Schuldners“. JA Juristische Arbeitsblätter 52, br. 1 (2020): 8-12.

6. Neumayer, Georgia. „Das Zahlungsverzugsgesetz“. Zivilrecht aktuell 9, br. 10 (2013): 187-190. 
7. Oelsner, Tobias. „Auswirkungen des Umsetzungsverzugs bei der Zahlungsverzugsrichtlinie“. NJW - Neue Juristische Wochenschrift 66, br. 34 (2013): 2469-2474.

8. Oelsner, Tobias. „Die Neufassung der Zahlungsverzugsrichtlinie“, EuZW - Europäische Zeitschrift für Wirtschaftsrecht 22, br. 24 (2011): 940-947.

9. Spitzer, Albert. „Das Gesetz zur Bekämpfung von Zahlungsverzug im Geschäftsverkehr“. MDR - Monatsschrift für Deutsches Recht 68, br. 16 (2014): 933-939.

10. Stöber, Michael i Petanidis, Georgios. „Die Verzugspauschale nach $\S 288$ Abs. 5 BGB im Lichte der EU-Zahlungsverzugsrichtlinie“. AGS - Anwaltsgebühren spezial 8, br. 1 (2017): 1-5.

11. Tot, Ivan. „Late Payment Directive: Recent and Pending Cases at the Court of Justice“. InterEULawEast 3, br. 2 (2016): 71-86.

12. Tot, Ivan. „Novo posebno uređenje zateznih kamata - specifičnosti, polje primjene i usklađenost s pravnom stečevinom Europske unije“. Zbornik Pravnog fakulteta Sveučilišta u Rijeci 35, br. 1 (2014): 271-309.

13. Tot, Ivan. „Pojam i pravne posljedice zakašnjenja s plaćanjem u trgovačkim ugovorima u pravu Europske unije“. Zbornik Pravnog fakulteta Sveučilišta u Rijeci 33, br. 2 (2012): 769-801.

14. Verse, Dirk A. „Das Gesetz zur Bekämpfung von Zahlungsverzug im Geschäftsverkehr“. ZIP - Zeitschrift für Wirtschaftsrecht 34, br. 38 (2014): 1809-1818.

15. Weller, Marc-Philippe i Harms, Charlotte Sophie. „Die Kultur der Zahlungstreue im BGB - Zur Umsetzung der neuen EU-Zahlungsverzugsrichtlinie ins deutsche Recht". WM Wertpapier-Mitteilungen 66, br. 49 (2012): 2305-2314.

Sudska praksa Suda EU-a:

1. Presuda od 16. veljače 2017., IOS Finance C-555/14, EU:C:2017:121

Prijedlozi propisa, pripremni materijali i sl.:

1. Prijedlog Zakona o izmjenama i dopunama Zakona o financijskom poslovanju i predstečajnoj nagodbi, s konačnim prijedlogom Zakona, predlagatelja Vlade Republike Hrvatske, 20.6.2013., P.Z.E. br. 413.

Pravni propisi Europske unije:

1. Direktiva 2000/35/EZ Europskog parlamenta i Vijeća od 29. lipnja 2000. o borbi protiv kašnjenja u plaćanju u poslovnim transakcijama, SL L 200, 8.8.2000.

2. Direktiva 2011/7/EU Europskog parlamenta i Vijeća od 16. veljače 2011. o borbi protiv kašnjenja u plaćanju u poslovnim transakcijama, SL L 48, 23.2.2011.

Pravni propisi država članica Europske unije:

Austrija, Republika

1. Opći građanski zakonik (Allgemeines bürgerliches Gesetzbuch für die gesammten deutschen Erbländer der Oesterreichischen Monarchie), Justizgesetzsammlung, br. 946/1811., s posljednjom izmjenom od 29.10.2019., Bundesgesetzblatt I, br. 105/19.

2. Poduzetnički zakonik (Unternehmensgesetzbuch - Bundesgesetz über besondere zivilrechtliche Vorschriften für Unternehmen), Deutsches Reichsgesetzblatt, br. 23/1897., s posljednjom izmjenom od 23.7.2019., Bundesgesetzblatt, br. 22/15.

Belgija, Kraljevina

1. Zakon o borbi protiv zakašnjenja s plaćanjem u trgovačkim transakcijama (Loi concernant la lutte contre le retard de paiement dans les transactions commerciales), Moniteur belge, br. 247/02., s posljednjom izmjenom od 28.5.2019., Moniteur belge, br. 75/19. 
Bugarska, Republika

1. Trgovački zakon (Tărgovski zakon), Dăržaven vestnik, br. 48/91., s posljednjom izmjenom od 22.10.2019., Dăržaven vestnik, br. 83/19.

Cipar, Republika

1. Zakon br. 123 o borbi protiv zakašnjenja s plaćanjem u trgovačkim transakcijama (Nómos n. 123 o Perí tis Katapolémisis ton Kathysteríseon Pliromón stis Emporikés Synallagés), Episimi Efimerida, br. 4349/12.

\section{Češka Republika}

1. Građanski zakonik (Občanský zákoník), Sbírka zákonů, br. 33/12., s posljednjom izmjenom od 16.8.2018., Sbírka zákonů, br. 87/18.

2. Uredba Vlade br. 351/2013. (Nařizení vlády č. 351/2013) od 16. rujna 2013., Sbírka zákonů, br. 139/13.

Danska, Kraljevina

1. Zakon o kamatama i drugim pitanjima u slučaju zakašnjenja s plaćanjem (Lov om renter og andre forhold ved forsinket betaling (renteloven)), Lovtidende A, br. 743/02., s posljednjom izmjenom od 9.11.2015., Lovtidende A, br. 1237/15.

Estonija, Republika

1. Zakon o obligacijama (Võlaõigusseadus), Riigi Teataja I, br. 81/01., s posljednjom izmjenom od 14.12.2019.

Finska, Republika

1. Ovršni zakon (Laki saatavien perinnästä), Finlex, br. 513/99., s posljednjom izmjenom od 1.9.2019., Finlex, br. 598/19.

2. Zakon o rokovima plaćanja u trgovačkim transakcijama (Laki kaupallisten sopimusten maksuehdoista), Finlex, br. 30/13., s posljednjom izmjenom od 15.4.2016., Finlex, br. $243 / 16$.

Francuska, Republika

1. Dekret br. 2013-269 od 29. ožujka 2013. o borbi protiv zakašnjenja s plaćanjem u ugovorima o javnoj nabavi (Décret $n^{\circ} 2013-269$ du 29 mars 2013 relatif à la lutte contre les retards de paiement dans les contrats de la commande publique), Journal Officiel de la République Française, br. 77/13.

2. Dekret br. 2018-1075 od 3. prosinca 2018. o regulatornom dijelu zakonika o javnoj nabavi (Décret $n^{\circ} 2018-1075$ du 3 décembre 2018 portant partie réglementaire du code de la commande publique), Journal Officiel de la République Française, br. 281/18.

3. Trgovački zakonik (Code de commerce), Legifrance, pročišćeni tekst od 1.1.2020.

4. Zakonik o javnoj nabavi (Code de la commande publique), Legifrance, pročišćeni tekst od 1.1.2020.

Helenska Republika

1. Zakon br. $4152 / 2013$ o žurnoj implementaciji zakona 4046/2012, 4093/2012 i 4127/2013 (Nomos 4152/2013 Epeigonta métra efarmogis ton nómon 4046/2012, 4093/2012 kai 4127/2013), Efimerís tis Kyverníseos, br. 107/13.

Hrvatska, Republika

1. Zakon o financijskom poslovanju i predstečajnoj nagodbi, Narodne novine, br. 108/12., 144/12., 81/13., 112/13., 71/15., 78/15.

2. Zakon o obveznim odnosima, Narodne novine, br. 35/05., 41/08., 125/11., 78/15., 29/18. 
Irska, Republika

1. Uredba o zakašnjenju s plaćanjem u trgovačkim transakcijama iz 2012. (European Communities (Late Payment in Commercial Transactions) Regulations 2012), Statutory Instrument, br. 580/12., s posljednjom izmjenom putem Uredbe iz 2016. (European Communities (Late Payment in Commercial Transactions) (Amendment) Regulations 2016), Statutory Instrument, br. 281/16.

Latvija, Republika

1. Građanski zakonik (Civillikums), Valdības Vēstnesis, br. 41/1937., s posljednjom izmjenom od 5.12.2019., Latvijas Vēstnesis, br. 246/19.

Litva, Republika

1. Zakon Republike Litve o sprječavanju zakašnjenja s plaćanjem u trgovačkim transakcijama (Lietuvos Respublikos mokejimu, atliekamu pagal komercinius sandorius, vélavimo prevencijos įstatymo), Valstybės žinios, br. 127-6389/12.

Luksemburg, Veliko Vojvodstvo

1. Zakon od 18. travnja 2004. o rokovima plaćanja i zateznim kamatama (Loi du 18 avril 2004 relative aux délais de paiement et aux intérêts de retard), Memorial A, br. 66/04., s posljednjom izmjenom od 29.3.2013., Memorial A, br. 67/13.

Mađarska

1. Zakon IX. iz 2016. o paušalnoj naknadi troškova naplate (2016. évi IX. törvény a behajtási költségátalányról), Magyar Közlöny, br. 39/16.

Malta, Republika

1. Trgovački zakonik (Kodici tal-Kummerč / Commercial Code) od 2.10.1857., s posljednjom izmjenom od 17.1.2014., Government Gazette of Malta, br. 19,196/14.

Nizozemska, Kraljevina

1. Građanski zakonik - Knjiga 6 (Burgerlijk Wetboek Boek 6), s posljednjom izmjenom od 21.7.2019., Staatdsblad, br. 190/19.

Njemačka, Savezna Republika

1. Građanski zakonik (Bürgerliches Gesetzbuch in der Fassung der Bekanntmachung vom 2. Januar 2002), Bundesgesetzblatt I, br. 2/02., s posljednjom izmjenom od 21.12.2019., Bundesgesetzblatt I., br. 52/19.

Poljska, Republika

1. Zakon od 8. ožujka 2013. o rokovima plaćanja u trgovačkim transakcijama (Ustawa z dnia 8 marca 2013 o terminach zapłaty w transakcjach handlowych), Dziennik Ustaw, br. 403/13., s posljednjom izmjenom od 11.9.2019., Dziennik Ustaw, br. 2020/19.

Portugal, Republika

1. Zakonodavni dekret br. 62/2013 (Decreto-Lei $n .^{\circ}$ 62/2013), Diário da República - Série I, br. 90/13.

Rumunjska

1. Zakon br. $72 / 2013$ o mjerama za borbu protiv zakašnjenja s plaćanjem (Legea nr. 72/2013 privind măsurile pentru combaterea întârzierii în executarea obligațiilor de plată a unor sume de bani rezultând din contracte încheiate între profesioniști și între aceștia și autorități contractante), Monitorul Oficial, br. 182/13. 
Slovačka Republika

1. Trgovački zakonik (Obchodný zákonník), Zbierka zákonov, br. 98/91., s posljednjom izmjenom od 5.6.2019., Zbierka zákonov, br. 156/19.

2. Uredba Vlade Slovačke Republike o provedbi pojedinih odredbi Trgovačkog zakonika (Nariadenie vlády Slovenskej republiky, ktorým sa vykonávajú niektoré ustanovenia Obchodného zákonníka), Zbierka zákonov, br. 21/13.

Slovenija, Republika

1. Zakon o sprječavanju zakašnjenja s plaćanjem (Zakon o preprečevanju zamud pri plačilih), Uradni list, br. 57/12.

Španjolska, Kraljevina

1. Zakon 3/2004 od 29. prosinca kojim se uspostavljaju mjere za borbu protiv zakašnjenja s plaćanjem u trgovačkim tranakcijama (Ley 3/2004, de 29 de diciembre, por la que se establecen medidas de lucha contra la morosidad en las operaciones comerciales), Boletín Oficial del Estado, br. 314/04., s posljednjom izmjenom od 30.9.2014., Boletín Oficial del Estado, br, 238/14.

Švedska, Kraljevina

1. Zakon (1981: 739) o nadoknadi troškova naplate, itd. (Lag (1981:739) om ersättning för inkassokostnader m.m.), Svensk författningssamling, br. 739/81., s posljednjom izmjenom od 14.2.2013., Svensk författningssamling, br. 56/13.

\section{Talijanska Republika}

1. Zakonodavni dekret br. 231 od 9. listopada 2002. o implementaciji Direktive 2000/35/ EZ o borbi protiv kašnjenja u plaćanju u trgovačkim transakcijama (Decreto legislativo 9 ottobre 2002, n. 231, Attuazione della direttiva 2000/35/CE relativa alla lotta contro $i$ ritardi di pagamento nelle transazioni commerciali), Gazetta Ufficiale, br. 249/02., s posljednjom izmjenom od 30.10.2014., Gazetta Ufficiale, br. 261/14.

Ujedinjeno Kraljevstvo Velike Britanije i Sjeverne Irske

1. Zakon o zakašnjenju s plaćanjem trgovačkih dugova (o kamatama) (The Late Payment of Commercial Debts (Interest) Act 1998), UK Public General Acts, br. 20/98., s posljednjom izmjenom od 26.2.2018., UK Statutory Instruments, br. 117/18. 


\author{
Ivan Tot*
}

Summary

\title{
A SPECIAL COMPENSATION FOR THE CREDITOR'S RECOVERY COSTS INCURRED DUE TO DEBTOR'S LATE PAYMENT IN COMMERCIAL TRANSACTIONS (LUMP SUM COMPENSATION FOR RECOVERY COSTS)
}

One of the novelties introduced into Croatian law with the Financial Operations and Pre-Bankruptcy Settlement Act of 2012 (ZFPPN) is the introduction of a new legal consequence of late payment in the so-called commercial transactions. On the basis of Art. 13 (1) of the ZFPPN, the creditor of a monetary obligation is ex lege entitled to a lump sum compensation for recovery costs in Croatian kunas in the amount equivalent of forty euros. This lump sum compensation, designated in the ZFPPN as "a special compensation for the creditor's recovery costs incurred due to debtor's late payment in commercial transactions", was introduced into Croatian law in order to comply with the provisions of the Art. 6 Directive 2011/7/EU. The paper discusses the legal nature and functions of the lump sum compensation for recovery costs and analyses the conditions for the arising of the creditor's right to a lump sum compensation, maturity and prescription of the claim to a lump sum compensation. The interpretation of the provisions of the ZFPPN in this paper is based on a comparative legal analysis and is in line with the Directive 2011/7/EU. In the utilisation of the comparative method, the solutions adopted in Austrian and German law were primarily considered, while the research also included the laws and regulations of all EU Member States that were adopted in the tranposition of the provisions of Art. 6. Directive 2011/7/EU.

Keywords: late payment; commercial transactions; lump sum compensation for recovery costs; Directive 2011/7/EU.

* Ivan Tot, Ph.D., Assistant Professor, University of Zagreb, Faculty of Economics; itot@net. efzg.hr. 
Zusammenfassung

\section{SONDERSCHADENERSATZ FÜR DEN ZAHLUNGSVERZUG DES SCHULDNERS BEI GESCHÄFTSTRANSAKTIONEN (PAUSCHALBETRAG FÜR BETREIBUNGSKOSTEN)}

Eine der Neuheiten, die mit dem Gesetz über Finanzgeschäften und Insolvenzvergleich von 2012 (ZFPPN) in das kroatische Recht eingeführt wurde, ist die Einführung einer neuen Rechtsfolge bei Zahlungsverzug des Schuldners bei den sogenannten Geschäftstransaktionen. Aufgrund Art. 13 Abs. 1 ZFPPN hat der Gläubiger einer Geldverpflichtung Recht auf Anspruch auf den Pauschalbetrag für Beitreibungskosten, wobei dieser Pauschalbetrag vierzig Euro im Gegenwert von Kuna beträgt. Dieser Pauschalbetrag, der im ZFPPN als „Sonderschadenersatz für den Zahlungsverzug des Schuldners bei Geschäftstransaktionen“ bezeichnet wird, wurde in das kroatische Recht eingeführt, um es an die Bestimmungen des Art. 6 der Richtlinie 2011/7/EU anzugleichen. Demzufolge erörtert dieser Beitrag den rechtlichen Charakter und die Funktionen des Pauschalbetrags für Beitreibungskosten und analysiert die Bedingungen für das Entstehen des Anspruchs des Gläubigers auf einen solchen Pauschalbetrag, die Fälligkeit und die Verjährung des Anspruchs auf einen Pauschalbetrag. Die Auslegung der Bestimmungen des ZFPPN in diesem Beitrag stützen sich auf einer rechtsvergleichenden Analyse und stehen im Einklang mit der Richtlinie 2011/7 / EU. Bei der Anwendung der Vergleichsmethode wurden in erster Linie die im österreichischen und deutschen Recht angenommenen Lösungen berücksichtigt, während die Untersuchung auch die Gesetze und Vorschriften aller EU-Mitgliedstaaten umfasste, durch welche im Nationalrecht die Bestimmungen von Art. 6 der Richtlinie 2011/7 / EU transponiert wurden.

Schlüsselwörter: Zahlungsverzug; Geschäftsverkehr;

Beitreibungskostenpauschale; Richtlinie 2011/7/EU. 
Riassunto

\section{UN RISARCIMENTO SPECIALE DEI COSTI DI RECUPERO DEL CREDITORE SOSTENUTI A CAUSA DEL RITARDO DI PAGAMENTO DEL DEBITORE IN TRANSAZIONI COMMERCIALI (UN RISCARCIMENTO FORFETTARIO DEI COSTI DI RECUPERO)}

Le novità introdotte dalla Legge sulle attività finanziarie e sul concordato preventivo (ZFPPN) nel 2012 è l'introduzione di nuove conseguenze giuridiche della mora del pagamento del debitore nelle cosiddette transazioni commerciali. Con la disposizione dell'art. 13, para. 1 del ZFPPN, il creditore dell'obbligazione pecuniaria è autorizzato ex lege a richiedere dal debitore un risarcimento forfettario pari all'ammonto che corrisponde al contravalore di quaranta euro in moneta nazionale. Questo risarcimento forfettario che il ZFPPN denomina "un risarcimento specifico per i costi arrecati al creditore causati dalla mora del debitore all'adempimento dell'obbligazione pecuniaria nelle transazioni commerciali" è stato introdotto nel diritto croato ai fini di conformarsi con le disposizioni dell' art. 6 della Direttiva 2011/7/ EU. Nel lavoro si discute della natura legale e delle funzioni di esso. Si analizzano i presupposti per il sorgimento del diritto del creditore al risarcimento forfettario, l'esigibilità e la prescrizione della richiesta per l'erogazione di questo risarcimento. Le interpretazioni del ZFPPN esposte nel lavoro sono basate sull'analisi giuridicocomparata e sull'interpretazione armonizzata del ZFPPN con la Direttiva 2011/7/ EU. Nell'applicazione del metodo di analisi giuridico-comparata sono stati trattati gli orientamenti del diritto austriaco e tedesco, mentre la ricerca comprende anche i regolamenti di tutti gli Stati membri dell'Unione europea nei quali le disposizioni dell'art. 6 della Direttiva 2011/7/EU sono state trasportate nel diritto nazionale.

Parole chiave: ritardo di pagamento; transazioni commerciali; risarcimento forfettario dei costi di recupero; Direttiva 2011/7/UE. 